\title{
Phosphatic Clay for Agricultural Uses: Bibliography 1
}

\section{E.A. Hanlon, J.A. Stricker, and J. Carson ${ }^{2}$ \\ Introduction}

Phosphatic clays are by-products of the phosphate mining industry in central Florida. These clays have unique properties, including approximately $2 \%$ phosphorus, which remains after the mining and beneficiation processes. Compared to the sandy soils of Florida, phosphatic clays are highly fertile with high water holding capacity. As of this writing, there are more than 100,000 acres of phosphatic clays within Florida. Research and extension efforts have focused on identifying the benefits, risks, and challenges of using phosphatic clays in agricultural production while protecting Floridas natural environment.

The following is a structured bibliography of information that was generated in large part by the Polk County Mined Lands Agricultural Research and Demonstration Project with related research programs and documents. This joint project between the University of Florida, Institute of Food and Agricultural Sciences (IFAS); the Florida Institute of Phosphate Research (FIPR); Natural Resource and Conservation Service (NRCS); and the Polk County Board of County Commissioners addressed the problems and opportunities presented by phosphatic clays.

This document can be used by growers, land owners, government agency staff members, and elected officials who wish to know more about phosphatic clay as a valuable resource of Florida. This bibliography is divided into sections based upon subject area. The contents of this EDIS document shall be updated in 2008 following the normal UF/IFAS three-year revision policy.

\section{General overview of phosphatic clays}

Documents in this section describe the creation of phosphatic clays during the mining operations, transport, deposition, reclamation including dewatering, and findings at selected states of completion.

\section{Journal Articles}

Hochmuth, G.J., E.A. Hanlon, and J.A. Stricker. 1986. Production of high-value crops on reclaimed phosphate mined lands. Am. Soc. Hort. Sci. 4-16 Aug. HortScience 21:738.

1. This document is SL224 a fact sheet of the Soil and Water Science Department, Florida Cooperative Extension Service, Institute of Food and Agricultural Sciences, University of Florida. Original publication date: April 2005. Visit the EDIS Web Site at http://edis.ifas.ufl.edu.

2. Edward A. Hanlon, professor, Soil and Water Science Department, Southwest Florida Research and Education Center, Immokalee, FL; James A. Stricker, Polk County Extension Director and Extension Agent IV (retired), Bartow, FL; and J Carson, Media Coordinator, Southwest Florida Research and Education Center, Immokalee, FL, Florida Cooperative Extension Service, Institute of Food and Agricultural Sciences, University of Florida, Gainesville, FL 32611 .

The Institute of Food and Agricultural Sciences (IFAS) is an Equal Opportunity Institution authorized to provide research, educational information and other services only to individuals and institutions that function with non-discrimination with respect to race, creed, color, religion, age, disability, sex, sexual orientation, marital status, national origin, political opinions or affiliations. U.S. Department of Agriculture, Cooperative Extension Service, University of Florida, IFAS, Florida A. \& M. University Cooperative Extension Program, and Boards of County Commissioners Cooperating. Larry Arrington, Dean 
Hochmuth, G.J., E.A. Hanlon, and J.A. Stricker. 1987. Crop production on reclaimed phosphate-mined soils in Florida. HortScience 22:189-191.

\section{Proceedings and Florida Journals}

Stricker, J.A. 1991. Agricultural use of reclaimed phosphate waste clays, In Proc. 41st Annual Meeting of the Fertilizer Industry Round Table, Tampa, FL. Oct. 21-23. The Fertilizer Industry Round Table, Washington, DC. p. 98-104.

Stricker, J.A. 2000. High value crop potential of reclaimed phosphatic clay soil. In Proc. Amer. Soc. Surface Mining and Reclamation. Annual Meeting of the Amer. Soc. Surface Mining and Reclamation. Tampa, FL. 11-15 June. 11 pp.

\section{Reports and Dissertations}

Zang, P. and G.R. Albarelli. 1995. Phosphatic clay bibliography. Florida Institute of Phosphate Research, Bartow, FL. Publication No. 02-097-114. 322 pp.

\section{Abstracts}

Bondurant, M., and E.A. Hanlon. 1991. Agricultural alternatives for the clay wastes of phosphate mining. Mined Lands Agricultural Research/Demonstration Project. Fla. Coop. Extn. Serv., IFAS, Univ. of Fla., Gainesville, FL. 2 pp.

Hanlon, E.A. 1988. Mined lands agricultural research/demonstration project research plan. Fla. Coop. Extn. Serv., IFAS, Univ. of Fla., Gainesville, FL. 5 pp.

Stricker, J.A., E. Caldwell, M.F. Cole, E.A. Hanlon, G.J. Hochmuth, W.D. Mulkey, G.M. Price, L.N. Shaw, J. Tallent, and F. Wilson. 1987. Mined lands program launched by cooperative effort. Fla. Assoc. of County Agric. Agents. Abst. 1 p.

\section{Extension Publications}

Stricker, J.A. 1993. A brief overview of the Polk County mined lands agricultural research/demonstration project, Oct. 1985 to Feb. 1993. Univ. of Fla./Polk County Coop. Extn. Serv. Bartow, FL. Xerox, 6 pp.

\section{Presentations, Videos, and Training Sessions}

English Language Institute Seminar. 1989. Reclamation of phosphatic clays in central Florida. Gainesville, FL. Attendance: 15.

Field Day. 1987. Polk County agricultural research/demonstration project: Soils management. Attendance: 64 including the Lt. Governor and other state political figures.

Field Day. 1989. Tillage and soil management of phosphatic clays. (four 15-minute presentations). Bartow, FL. Attendance: 150.

Grower meeting. 1990. Use of phosphatic clays. (one-day workshop, chair: Hanlon, E.A.). Bartow, FL. Attendance: 50.

\section{Soils}

Because phosphatic clay is much different than the traditional sandy soils of Florida, many management aspects of phosphatic clay in an agricultural setting are addressed. Steps in reclamation, surface drainage (macrobeds), erosion prevention, tillage and surface roughness, water-table management, bed-mellowing (clod reduction), trafficability, and selection of tillage equipment for selected operations are explained. (See Radionuclide section below).

\section{Proceedings and Florida Journals}

Stricker, J.A. 2004. Stormwater Runoff from Phosphatic Clay Soiland Estimated Cost. Soil Crop Sci. Soc. Florida Proc. 63:84.

\section{Reports and Dissertations}

Haman, D.Z., E.A. Hanlon, J.A. Stricker, D.L. Anderson, G. Gao, and W.R. Reck. 2001. Managing runoff water quality from clay settling areas used for intensive agricultural production. 
Florida Institute of Phosphate Research.

Bartow, FL. Pub. No. 03-114-146. 57 pp.

\section{Hanlon, E.A., R.A. Jerez, and J.A. Stricker (eds.) 1996. The mined lands agricultural research and demonstration project: Summary of experiments and extension recommendations. Florida Institute of Phosphate Research. Bartow, FL. Pub. No. 03-093-128. 115 pp.}

The following articles are found in the reference cited above in bold font.

Hanlon, E.A., R.A. Jerez, J.A. Stricker, D.B. Shibles, and T.C. Riddle. 1996. Naturally occurring radionuclides in agricultural products. p. 16-26.

Hanlon, E.A., R.A. Jerez, D.B. Shibles, and T.C. Riddle. 1996. Drainage control. p. 33-35.

Hanlon, E.A., R.A. Jerez, E.C. French, and T.C. Riddle. 1996. Perennial peanut for trafficability. p. 36-39.

Jerez, R.A., E.A. Hanlon, and G.J. Hochmuth. 1996. Seedbed preparation. p. 31-32.

Schwandes, L., R.A. Jerez, E.A. Hanlon, and G.J. Hochmuth. 1996. Comparison of soil extractants. p. 27-30.

Shibles, D.B. (ed.) 1994. Polk County mined lands agricultural research/demonstration project report: Three-year summary. Florida Institute of Phosphate Research. Bartow, FL. FIPR Publ. No. 03-088-107.

The following articles are found in the reference cited above in bold font.

Hanlon, E.A., D. Shibles, and F. Mallory. 1994. Macrobed construction. p. 83-88.

Hanlon, E.A., G.J. Hochmuth, and T.C. Riddle. 1994. Tillage equipment selection for vegetable bed preparation. p. 89-90.

Shibles, D.B., T.C. Riddle, and E.A. Hanlon. 1994. Dewatering studies. p. 112-116.

\section{Abstracts}

French, E.C., and E.A. Hanlon. 1990. Perennial peanut sod: a stabilizing rhizome matrix for moist phosphatic clay soil. Soil Sci. Soc. Am. San Antonio, TX, 21-26 Oct. Agron. Abst. p. 142.

Gao, D., and E.A. Hanlon. 1997. Sediments and associated $\mathrm{P}$ in runoff from reclaimed phosphatic clay. Environ. Chem. Workshop, Indiana Univ. Bloomington, IN, 8-9 Nov. (Abstract).

Hanlon, E.A. 1991. Symposium synopsis addressing naturally occurring radionuclides in agriculture products. Soil Sci. Soc. Am. Denver, CO, 27 Oct.-1 Nov. Agron. Abst. p. 289.

Hanlon, E.A., J.C. Graddy, and J.A. Valenti. 1992. Naturally occurring radionuclides in agricultural products: Extension efforts. Am. Soc. Agron. Minneapolis, MN, 1-6 Nov. Agron. Abst. p. 27.

Jerez, R.A., E.A. Hanlon, and G.J. Hochmuth. 1988. Use of a relief meter in the reclamation process of phosphatic clays in Florida. Soil Sci. Soc. Am. Anaheim, CA, 27 Nov.-2 Dec. Agron. Abst. p. 277.

Patel, S.K., J.B. Sartain, S.G. Richardson, and E.A. Hanlon. 1991. Effects of dolomite, phosphatic clay, and sewage sludge on the $\mathrm{pH}$ and electrical conductivity of phosphogypsum. Soil Sci. Soc. Am. Denver, CO, 27 Oct.-1 Nov. Agron. Abst. p. 250.

\section{Extension Publications}

Hanlon, E.A, and R.D. Ford. 1994. Reclaimed phosphatic clays: surface drainage and water table measurements. Univ. of Fla. Coop. Extn. Serv., Gainesville, FL. SS-MLR-6. 4 pp.

Hanlon, E.A., G.J. Hochmuth, L. Shaw, and C. Riddle. 1993. Tillage for vegetable-crop production on phosphatic clays. Mined Lands Agricultural Research/Demonstration Project. Production Guide SS-MLR-4. 6 pp. 
Hanlon, E.A., H.W. Kananen, and E.C. French. 1994. Guidelines for reclaiming clay settling areas for intensive agricultural uses. Univ. of Fla. Coop. Extn. Serv., Gainesville, FL. SS-MLR-1. 7 pp.

\section{Presentations, Videos, and Training Sessions}

Gao, D., and E.A. Hanlon. 1995. Application of GLEAMS to estimate runoff, erosion, and nutrient losses from phosphatic clay. Presentation: Soil Crop Sci. Soc. Fla., Daytona Beach, FL.

Hanlon, E.A. 1990. Soil management of phosphatic clays. (eight minutes of 22-minute video). Bartow, FL.

Hanlon, E.A., J.A. Stricker, D.Z. Haman, D.L. Anderson. 1996. Runoff water quality from clay settling areas used for intensive agricultural production. Invited. 11th Annual Regional Phosphate Conference, Am. Inst. Mining Eng., 18 Oct. Lakeland, FL.

\section{Agronomic crops}

Articles address rice, perennial peanut, bio-mass crops, and selected row crop production practices on phosphatic clay.

\section{Journal Articles}

French, E.C., E.A. Hanlon, and G.J. Hochmuth. 1989. Perennial peanut-corn association on phosphatic clay settling pond soil. Fla. Acad. Sci. Orlando, FL. 12 Apr. Vol. 52:4.

Mislevy, P., W.G. Blue, and C.E. Roessler. 1989. Productivity of clay tailings from phosphate mining. I. Biomass crops. J. Environ. Qual. 18:95-100.

\section{Proceedings and Florida Journals}

Baltensperger, D.D., G.M. Prine, and D.S. Wofford. 1989. Phosphatic settling pond clays as potential forage legume seed production site. $\mathrm{p}$. 1627-1628. In Proceedings XVI International Grassland Congress at Nice, France.
French, E.C., G.M. Prine, E.A. Hanlon, J.A. Stricker, D.B. Shibles, and C. Riddle. 1992. Rhizoma peanut establishment in phosphatic clay. Fla. Acad. Sci. Orlando, FL., 21 Apr. Vol. 55:4.

Prine, G.M., D.L. Rockwood, and J.A. Stricker. 2000. Many short rotation trees and herbaceous plants available as energy crops in humid lower south. In Proc. Of Bioenergy 2000, Northeast Regional Biomass Program, 400 N. Capital St., NW, Suite 382, Washington, DC, Oct. 15-19.

Prine, G.M., and K.R. Woodard. 1994. Leucaena and tall grasses as energy crops in humid Lower South USA. p. 681-688. In Proc. Sixth National Bioenergy Conf.: Bioenergy 94, Using Biofuels for a Better Environment. Reno/Sparks, NV. 2-6 Oct. Vol. 2.

Segrest, S.A., D.L. Rockwood, J.A. Stricker, A.E.S. Green, W.H. Smith, and D.R. Carter. 1998. Biomass co - Firing with coal at Lakeland, Florida, utilities. In Proc. BioEnergy 98, Expanding BioEnergy Partnerships. Madison, WI. Oct. 4-8. p. 315-325.

Stricker, J.A., G.M. Prine, D.L. Anderson, D.B. Shibles, and T.C. Riddle. 1996. p. 822-829.

Biomass/energy crops grown on phosphatic clay in central Florida. In Proc. BioEnergy 96, Seventh National Bioenergy Conference. Nashville, TN. 15-19 Sept. Vol. 2.

Stricker, J.A., G.M. Prine, and T.C. Riddle. 1997. Yield of kenaf grown on two locations in Florida. Proc. Soil and Crop Sci. Fla. 56:35-37.

Stricker, J.A., G.M. Prine, K.R. Woodard, and D.B. Shibles. 1993. Biomass yield of tall grass energy crops on phosphatic clay in central Florida. Proc. Soil Crop Sci. Soc. Fla. 52:4-6.

Stricker, J.A., P.G. Tuohy, M. Rahmani, and A.W. Hodges. 1997. Scale-up of a dedicated biomass feedstock system for production of ethanol and electricity. In Proc. Third Biomass Conference of the Americas. Montreal, Quebec, Canada. Aug 24-29. p 1093-1101. 


\section{Reports and Dissertations}

Eitzen, J.B. 1990. Ratoon rice analysis on phosphatic clay soil. Univ. of Fla. Dissertation. $144 \mathrm{pp}$.

Proc. first biomass conf. of the Americas: Energy, environment, agriculture, and industry. 1993. Burlington, VT. 30 Aug.-2 Sept. Vol. 1.

The following articles are found in the reference cited above in bold font.

Prine, G.M., and K.R. Woodard. 1993. Herbaceous energy crops in humid Lower South USA. p. 278-279.

Stricker, J.A., G.M. Prine, K.R. Woodard, D.L. Anderson, D.B. Shibles, and T.C. Riddle. 1993. Production of biomass/energy crops on phosphatic clay soils in central Florida. p. 254-259.

Proc. second biomass conf. of the Americas:

Energy, environment, agriculture and industry. 1995. Portland, OR. 21-24 Aug.

The following articles are found in the reference cited above in bold font

Prine, G.M. 1995. Chemical composition of biomass from tall perennial tropical grasses. p. 278-287.

Stricker, J.A., A.W. Hodges, M. Rahmani, J.W. Mishoe, G.M. Prine, D.L. Rockwood, and A. Vincent. 1995. Economic development through biomass systems integration in central Florida. p. 1608-1617.

\section{Hanlon, E.A., R.A. Jerez, and J.A. Stricker (eds.) 1996. The mined lands agricultural research and demonstration project: Summary of experiments and extension recommendations. Florida Institute of Phosphate Research. Bartow, FL. Pub. No. 03-093-128. 115 pp.}

The following articles are found in the reference cited above in bold font.
French, E.C., G.M. Prine, and E.A. Hanlon. 1996. Perennial peanut production. p. 99-102. Text adapted by R.A. Jerez and E.A. Hanlon.

French, E.C., G.M. Prine, T.C. Riddle, D.B. Shibles, J.A. Stricker, and W.D. Pitman. 1996. Alfalfa production on phosphatic clay. $\mathrm{p}$. 75-78. Text adapted by R.A. Jerez and E.A. Hanlon.

French, E.C., G.M. Prine, J.A. Stricker, T.C. Riddle, and D.B. Shibles. 1996. Multiple cropping on phosphatic clay soil. p. 93-96. Text adapted by R.A. Jerez and E.A. Hanlon.

French, E.C., G.M. Prine, J.A. Stricker, D.B. Shibles, and T.C. Riddle. 1996. Alfalfa and perennial peanut cutting frequency study. $\mathrm{p}$. 73-74.

French, E.C., T.C. Riddle, J.E. Hollister, and G.M. Prine. 1996. Overseeding of Florigraze perennial peanut with cool season crops. $p$. 97-98. Text adapted by R.A. Jerez and E.A. Hanlon.

Hanlon, E.A., R.A. Jerez, D.B. Shibles, and T.C. Riddle. 1996. Temperate field corn production. p. 110-111.

Pitman, W.D., E.C. French, and G.M. Prine. 1996. Perennial tropical legume screening on phosphatic clay. p. 103-105. Text adapted by R.A. Jerez and E.A. Hanlon.

Prine, G.M., E.C. French, T.C. Riddle, and J.A. Stricker. 1996. Rice production. p. 106-107. Text adapted by R.A. Jerez and E.A. Hanlon.

Prine, G.M., E.C. French, D.B. Shibles, and J.A. Stricker. 1996. Early grain sorghum trials on phosphatic clay soil. p. 79-83. Text adapted by R.A. Jerez and E.A. Hanlon.

Prine, G.M., E.C. French, and J.A. Stricker. 1996. Forage legume seed production. p. 84-85. Text adapted by R.A. Jerez and E.A. Hanlon. 
Prine, G.M., C.K. Hiebsch, E.C. French, and J.A. Stricker. 1996. Soybean cultivar performance. p. 108-109. Text adapted by R.A. Jerez and E.A. Hanlon.

Prine, G.M., R.C. Stephenson, E.C. French, and J.A. Stricker. 1996. Corn for grain and/or silage on phosphatic clays. p. 112-115. Text adapted by R.A. Jerez and E.A. Hanlon.

Prine, G.M., J.A. Stricker, E.C. French, D.B. Shibles, and T.C. Riddle. 1996. Kenaf, pulp and fiber crop for phosphatic clays. p. 90-92. Text adapted by R.A. Jerez and E.A. Hanlon.

Stricker, J. A, G. M. Prine, D. L. Anderson, D. B. Shibles, and T. C. Riddle. 1996.

Biomass/energy crops grown on phosphatic clay. p. 86-89. Text adapted by R.A. Jerez and E.A. Hanlon.

\section{Shibles, D. (ed.) 1994. Polk County mined lands agricultural research/demonstration project report: Three-year summary. Florida Institute of Phosphate Research. Bartow, FL. FIPR Publ. No. 03-088-107.}

The following articles are found in the reference cited above in bold font.

French, E.C., E.A. Hanlon, G.M. Prine, J.A. Stricker, D.B. Shibles, T.C. Riddle, and J.E. Spofford. 1994. Perennial peanut sod: A stabilizing rhizome matrix for moist phosphatic clay soil. p. 91-102.

French, E.C., W.D. Pitman, G.M. Prine, J.A. Stricker, D.B. Shibles, T.C. Riddle, and J.E. Spofford. 1994. Yield and quality comparison of alfalfa, perennial peanut, and desmanthus for livestock feed. p. 154-156.

French, E. C., G. M. Prine, E. A. Hanlon, J. A. Stricker, D. B. Shibles, T. C. Riddle, K. R. Woodard. 1994. Establishment strategies for forage perennial peanut on phosphatic clay. $\mathrm{p}$. 150-153.

French, E.C., G.M. Prine, C.K. Hiebsch, R.D. Barnett, J.A. Stricker, D.B. Shibles, T.C. Riddle, and K.R. Woodard. 1994. Multiple cropping on phosphatic clay soils in Polk County, Florida. p. 137-149.

Jones, D., J. Eitzen, and T.C. Riddle. 1994. Effect of main crop nitrogen fertilizer on ratoon yield. p. 179-186.

Jones, D.B, C. Riddle, and J. Eitzen. 1994. Rice performance trial. p. 170-178.

Mulkey, W.D., R.L. Clouser, and T.G. Taylor. 1994. Estimated production costs for selected vegetables produced on reclaimed phosphatic clay soils. p. 4-24.

Pitman, W.D. 1994. Alfalfa reseeding. p. 163-165.

Pitman, W.D. 1994. Perennial tropical legume screening on mined phosphatic clay. $p$. 156-162.

Rahmani, M., and R. Degner. 1994. Market opportunities for feed grains and alfalfa hay produced on reclaimed phosphatic clay in Florida. p. 25-50.

Shibles, D.B., E.A. Hanlon, and T.C. Riddle. 1994. Temperate field corn study. p. 166-169.

Stricker, J.A., and P.G. Tuohy. 1998. Dedicated feedstock supply system for production of ethanol and electricity. Final report. Southeast Regional Biomass Energy Program, Muscle Shoals, AL. Sept. 18. 13 pp.

\section{Abstracts}

French, E.C., and E.A. Hanlon. 1990. Perennial peanut sod: a stabilizing rhizome matrix for moist phosphatic clay soil. Soil Sci. Soc. Am. San Antonio, TX, 21-26 Oct. Agron. Abst. p. 142.

French, E.C., G.M. Prine, E.A. Hanlon, C. Riddle, D.B. Shibles, J.A. Stricker. 1993. Rhizoma peanut establishment in phosphatic clay. Am. Soc. Agron. Cincinnati, OH, 8-12 Nov. Agron. Abst. p. 135. 
Stricker, J.A. and G.M. Prine. 1998. Kenaf - a tree-free fiber crop for reclaimed phosphate land. Natural Resources Forum 98: Linkages in Ecosystem Science, Management and Restoration. June 9-10. Radisson Hotel, Gainesville, FL. p 162.

\section{Extension Publications}

Shibles, D B., J.A. Stricker, G.M. Prine, E.A. Hanlon, CR. Staples, E.C. French, and T.C. Riddle. 1994. Production and management of alfalfa on phosphatic clay in Florida. Univ. of Fla. Coop. Extn. Serv., Gainesville, FL. SS-MLR-2. 10 pp.

Stricker, J.A., G.M. Prine, D.L. Anderson, D.B. Shibles, and T.C. Riddle. 1993. Production and management of biomass/energy crops on phosphatic clay in central Florida. Univ. of Fla. Coop. Extn. Serv., Gainesville, FL. Cir. 1084. 8 pp.

Stricker, J.A., G.M. Prine, and T.C. Riddle. 1998. Kenaf-A possible new crop for central Florida. Univ. of Fla. Coop. Extn. Serv., Gainesville, FL. SS-AGR-68. 11 pp.

Talbot, M.T., S.A. Smith, R.L. Clouser, and T.G. Taylor. 1994. Economics of artificially drying alfalfa or perennial peanut for hay in central Florida. Univ. of Fla. Coop. Extn. Serv., Gainesville, FL. SS-MLR-9. 14 pp.

\section{Vegetable crops}

The fine-textured phosphatic clay required much less fertilization than vegetables produced on sandy soils. Irrigation was often needed to establish the crop, and transplanting was often superior to seeding. Crops included watermelon, tomato, bell pepper, squash, cabbage, and cauliflower.

\section{Reports and Dissertations}

\author{
Hanlon, E.A., R.A. Jerez, and J.A. Stricker \\ (eds.) 1996. The mined lands agricultural \\ research and demonstration project: \\ Summary of experiments and extension \\ recommendations. Florida Institute of \\ Phosphate Research. Bartow, FL. Pub. No. \\ 03-093-128. 115 pp.
}

The following articles are found in the reference cited above in bold font.

Jerez, R.A., E.A. Hanlon, and G.J. Hochmuth. 1996. Cucumber production. p. 51-62.

Jerez, R.A., E.A. Hanlon, and G.J. Hochmuth. 1996. Watermelon production. p. 63-65.

Jerez, R.A., E.A. Hanlon, and G.J. Hochmuth. 1996. Snap bean production. p. 66-68.

Jerez, R.A., E.A. Hanlon, and G.J. Hochmuth. 1996. Sweet corn. p. 69-71.

Jerez, R.A., E.A. Hanlon, and G.J. Hochmuth. 1996. Tomato production. p. 72

Shibles, D.B. (ed.) 1994. Polk County mined lands agricultural research/demonstration project report: Three-year summary. Florida Institute of Phosphate Research. Bartow, FL. FIPR Publ. No. 03-088-107.

The following articles are found in the reference cited above in bold font.

Hanlon, E.A., R.A. Jerez, G.J. Hochmuth, and T.C. Riddle. 1994. Sweet corn/sludge experiment (1989-1990). p. 103-111.

Hochmuth, G.J. 1994. Stand establishment experiment Oct. 26, 1989. p. 197-199.

Hochmuth, G.J. 1994. Vegetable production: Cultural and fertilizer studies. p. 200-215.

Hochmuth, G.J. 1994. Vegetable production: Stand establishment experiment Feb. 28, 1989. p. 187-196.

\section{Abstracts}

Hochmuth, G.J., and E.A. Hanlon. 1989. Production of summer squash on phosphatic clays of Florida. Fla. Coop. Extn. Serv., IFAS, Univ. of Fla., Gainesville, FL. Production Guide SS-MLR-902. 6 pp. 


\section{Extension Publications}

Hanlon, E.A., G.J. Hochmuth, and C. Riddle. 1992. Tillage for vegetable-crop production on phosphatic clays. Fla. Coop. Extn. Serv., IFAS, Univ. of Fla., Gainesville, FL. Production Guide SS-MLR-903. 6 pp.

\section{Sod production on phosphatic clays}

\section{Proceedings and Florida Journals}

Dudeck, A.E. 1990. Influence of planting method, fertility program, cultivar, and sod type on St. Augustinegrass. Proc. Fla. State Hort. Soc. 103:355

\section{Reports and Dissertations}

Freeman, T.E. (ed.) 1989. Turfgrass research in Florida. IFAS Tech. Report. Mar.

The following articles are found in the reference cited above in bold font.

Dudeck, A.E. 1989. Adaptation of St. Augustinegrass cultivars to reclaimed phosphate settling ponds. p. 27-32.

Dudeck, A.E. 1989. St. Augustinegrass establishment on reclaimed phosphate settling ponds. p. 21-26.

Dudeck, A.E. 1989. St. Augustinegrass fertilizer studies for sod production. p. 37-42.

Hanlon, E.A., R.A. Jerez, and J.A. Stricker (eds.) 1996. The mined lands agricultural research and demonstration project: Summary of experiments and extension recommendations. Florida Institute of Phosphate Research. Bartow, FL. Pub. No. 03-093-128. 115 pp.

The following article is found in the reference cited above in bold font.

Jerez, R.A., E.A. Hanlon, and A.E. Dudeck. 1996. Turfgrass production. p. 45-50.

Shibles, D.B. (ed.) 1994. Polk County mined lands agricultural research/demonstration project report: Three-year summary. Florida
Institute of Phosphate Research.

Bartow, FL. FIPR Publ. No. 03-088-107.

The following articles are found in the reference cited above in bold font.

Dudeck, A.E. 1994. Turfgrass production: Adaptation of St. Augustinegrass cultivars to reclaimed phosphate clay settling ponds. p. 231-235.

Dudeck, A.E. 1994. Turfgrass production: Influence of sod-soil type on St. Augustinegrass. p. 236-240.

Dudeck, A.E. 1994. Turfgrass production. St. Augustinegrass establishment on reclaimed phosphate settling ponds. p. 221-226.

Dudeck, A.E. 1994. Turfgrass production. St. Augustinegrass establishment on sand soil. p. 227-230.

Dudeck, A.E. 1994. Turfgrass production. St. Augustinegrass fertilizer studies for sod production. p. 216-220.

\section{Tree production on phosphatic clays}

\section{Proceedings and Florida Journals}

Segrest, S.A., D.L. Rockwood, D.R. Carter, W.H. Smith, A.E.S. Green and J.A. Stricker. 2004. Short rotation woody crops for co-firing in central Florida. In Barbara A. Sakkestad, ed. Proceedings of the $29^{\text {th }}$ International Technical Conference on Coal Utilization and Fuel Systems. April 18-22 . Coal Technology Association, Gaithersburg, MD. p. 139-148.

Segrest S.A., D.L. Rockwood, J.A. Stricker, and G.R. Alker. 2001. Partnering to cofire woody biomass in central Florida. Fifth Biomass Conference of the Americas. The Rosen Centre Hotel, Orlando, FL. September 17-21. 2 pp.

Stricker, J.A., D.L. Rockwood, S.A. Segrest, G.R. Alker, G.M. Prine, and D.R. Carter. 2000. Short rotation woody crops for Florida. In Proceedings of Third Biennial Conference, Short-Rotation Woody Crops Operations Working Group. State Univ. of New York, 
College of Environ. Sci. and Forestry. October 10-13. Syracuse, NY.

\section{Reports and Dissertations}

\begin{abstract}
Hanlon, E.A., R.A. Jerez, and J.A. Stricker (eds.) 1996. The mined lands agricultural research and demonstration project: Summary of experiments and extension recommendations. Florida Institute of Phosphate Research. Bartow, FL. Pub. No. 03-093-128.
\end{abstract}

The following article is found in the reference cited above in bold font.

Jerez, R.A., E.A. Hanlon, and E.F. Gilman. 1996. Tree production on reclaimed phosphatic clay. p. 40-44.

\section{Shibles, D. (ed.) 1994. Polk County mined} lands agricultural research/demonstration project report: Three-year summary. Florida Institute of Phosphate Research. Bartow, FL. FIPR Publ. No. 03-088-107.

The following article is found in the reference cited above in bold font.

Gilman, E.F. 1994. Woody ornamental production. p. 241-24.

\section{Extension Publications}

Gilman, E.F. 1994. Growing shade trees on reclaimed phosphatic clay settling ponds. Univ. of Fla., IFAS, Fla. Coop. Extn. Serv., Gainesville, FL. SS-MLR-3. 3 pp.

\section{Economics of agricultural activities on phosphatic clay}

The location of phosphatic clays and the associated climate limit the economic use of phosphatic clays for most vegetable and some agronomic crop production. Production costs, effects from established markets, and marketing windows can be found in these documents.

\section{Proceedings and Florida Journals}

Rahmani, M., A.W. Hodges, and J.A. Stricker. 1996. Potential producers and their attitudes toward adoption of biomass crops in central Florida. In Proc. Seventh National Biomass Conference. The Operyland Hotel, Nashville, TN. Sept. 15-20. p 822-829.

Rahmani, M., A.W. Hodges, J.A. Stricker, and C.F. Kiker. 1997. Economic analysis of biomass crop production in Florida. In Proc Third Biomass Conference of the Americas. Montreal, Quebec, Canada. Aug 24-29. p 91-99.

Rahmani, M., A.W. Hodges, J.A. Stricker and C.F. Kiker. 2003. Will investing in renewable energy pay off?: A case study in Florida. In Proc. Third Annual Conference, 2003 Hawaii International Conference on Business. Honolulu, HI. June 18-21 (CD ROM ISSN\#1539-722X).

Rahmani, M., A.W. Hodges, J.A. Stricker, C.F. Kiker, and P. Tuohy. Cost analysis of biomass to energy systems: a case study in central Florida. In H. Kopetz et al. (ed) Proc. International Conference, Biomass for Energy and Industry. Wurtzburg, Germany. June 8-11. p 1162-1165.

Segrest, S.A., D.L. Rockwood, J.A. Stricker, A.E.S. Green, W.H. Smith. 1998. Biomass co-firing with coal at Lakeland, FL, USA, Utilities. In H. Kopetz, et al. (ed.) Proc. International Conference, Biomass for Energy and Industry. June 8-11. Wurtzburg, Germany.

Stricker, J.A. 2004. Stormwater runoff from phosphatic clay soil and estimated cost. Soil Crop Sci. Soc. Fla. Proc. 63:84

Stricker, J.A., G.M. Prine and T.C. Riddle. 1998. Yield and estimated production cost for kenal at two locations in Florida. Proc. First Annual Meeting of the American Kenaf Society. Menger Hotel, San Antonio, TX, Feb. 25-26. p 109-119.

Stricker, J.A., S.A. Segrest, D.L. Rockwood, and G.M. Prine. 2000. Model fuel contract-co-firing biomass with coal. Proc. Soil and Crop Sci. Soc. Fla. 59:98-102. 


\section{Reports and Dissertations}

Pickett \& Associates, Inc. 2000. Cost estimate for treatment of runoff from a typical reclaimed clay settling area used for row crop production. UF/IFAS contract report. 20 pp.

Proc. second biomass conf. of the Americas: Energy, environment, agriculture and industry. 1995. Portland, OR. 21-24 Aug.

The following article is found in the reference cited above in bold font.

Stricker, J.A., A.W. Hodges, M. Rahmani, J.W. Mishoe, G.M. Prine, D.L. Rockwood, and A. Vincent. 1995. Economic development through biomass systems integration in central Florida. p. 1608-1617.

Rahmani, R., and R.L. Degner. 1990. Market opportunities for feed grains and alfalfa hay produced on reclaimed phosphatic clay in Florida. Fla. Agric. Market Res. Ctr., Food and Resource Economics Dept., IFAS, Univ. of Fla., Gainesville, FL. Ind. Rept. 90-2. 56 pp.

Shibles, D. (ed.) 1994. Polk County mined lands agricultural research/demonstration project report: Three-year summary. Florida Institute of Phosphate Research. Bartow, FL. FIPR Publ. No. 03-088-107.

The following articles are found in the reference cited above in bold font.

Mulkey, W.D., R.L. Clouser, and T.G. Taylor. 1994. Estimated production costs for selected vegetables produced on reclaimed phosphatic clay soils. p. 4-24.

Rahmani, M., and R. Degner. 1994. Market opportunities for feed grains and alfalfa hay produced on reclaimed phosphatic clay in Florida. p. 25-50.

\section{Extension Publications}

Talbot, M.T., S.A. Smith, R.L. Clouser, and T.G. Taylor. 1994. Economics of artificially drying alfalfa or perennial peanut for hay in central Florida. Univ. of Fla. Coop. Extn. Serv., Gainesville, FL. SS-MLR-9. 14 pp.

\section{Radionuclides in phosphatic clays}

Small amounts of radioactive substances, called radionuclides, are found in phosphatic clay. These articles describe work with beef cattle, agronomic crops, and the findings of a national symposium addressing radionuclides in agricultural products. While phosphatic clay does contain more radionuclides than adjacent mineral soils, researchers and food safety experts found that dietary health risks to humans were extremely low and declared agricultural products produced on phosphatic clay safe for entry into the human food chain. Since crops accumulate radionuclides at different rates, handling and preparation issues were described to further reduce possible exposure. Risk analysis showed that riding in a car today carries with that action a 1-in-4,000 chance of dying in a car accident. This risk is considered acceptable by millions of drivers. The risk of dietary exposure to radionuclides is many times less ( 1 in 1 million).

\section{Journal Articles}

Cowart, J.B., and W.C. Burnett. 1994. The distribution of uranium and thorium decay-series radionuclides in the environment-A review. J. Environ. Qual. 23:651-662.

Hanlon, E.A. 1994. Naturally occurring radionuclides in agricultural products-An overview. J. Environ. Qual. 23:630-632.

Linsalata, P. 1994. Uranium and thorium decay series radionuclides in human and animal food chains-A review. J. Environ. Qual. 23:633-642.

Million, J.B., J.B. Sartain, R.X. Gonzalez, and W.D. Carrier III. 1994. Radium-226 and calcium uptake by crops grown in mixtures of sand and clay tailings from phosphate mining. J. Environ. Qual. 23:671-676.

Mortvedt, J.J. 1994. Plant and soil relationships of uranium and thorium decay series radionuclides-A review. J. Environ. Qual. 23:643-650. 
Staples, C.R., R. Umana, J.A. Stricker, D. Shibles, M.J. Hayen, C.D. Hissem, D.S. Lough, and D.L. Demorest. 1994. Radionuclides in milk of dairy heifers raised on forages harvested from phosphatic clay soils on reclaimed mined land. J. Environ. Qual. 23:663-667.

Stricker, J.A., E.A. Hanlon, S.L. Sumner, D.B. Shibles, and R.L. West. 1994. Naturally occurring radionuclides in tissue from beef fed forages grown on phosphatic clay. J. Environ. Qual. 23:667-670.

\section{Proceedings and Florida Journals}

\section{Hanlon, E.A. (ed.) 1991. Symposium proceedings of naturally occurring radionuclides in agricultural products. Proc. Symposium UF/IFAS, FIPR, ASSMR, Fla. Chap. HPS, MLARD, Savannah River Ecol. Lab., and South. Regional Reclamation Committee (S-245) SSSA, Orlando, FL. 24-25 Jan.}

The following articles are found in the reference cited above in bold font.

Brown, C.E., D.G. Mose, G.W. Mushrush, and C.E. Chrosniak. 1991. Use of statistical techniques to assess the radon potential of rocks in parts of Virginia and Maryland. p. 35-54.

Cowart, J.B., and W.C. Burnett. 1991. The distribution of uranium and thorium decay-series radionuclides in the environment. p. 3-34.

Demorest, D. 1991. A discussion of the NORM issues in the petroleum and related industries. p. 244-245.

Demorest, D. 1991. Separation, isolation and analysis of low level natural occurring nuclides, Ra-226, Pb-210, Po-210 from biomaterial samples. p. 172-173.

Guidry, J.J., C.E. Roessler, W.E. Bolch, J.T. McClave, C.C. Hewett, and T.E. Abel. 1991. Radioactivity in foods grown on mined phosphate lands. p. 164-171.
Henderson, J., and T. Yarbrough. 1991. Removal of NORM deposits from process equipment. p. 246-259.

Linsalata, P. 1991. Uranium and thorium decay series radionuclides in human and animal food chains-A review. p. 115-145.

Million, J.B., J.B. Sartain, R.X. Gonzalez, and W.D. Carrier III. 1991. Radium-226 and calcium uptake by crops grown in mixtures of sand and clay tailings from phosphate mining. p. $78-89$.

Mislevy, P., C.E. Roessler, and W.G. Blue. 1991. Radium-226 uptake and dry matter yield for selected field, forage, and biomass crops grown on a phosphatic clay settling area. $\mathrm{p}$. 90-114.

Mortvedt, J.J. 1991. Plant and soil relationships of uranium and thorium decay series radionuclides. p. 55-77.

Mose, D.G., G.W. Mushrush, and C.E. Chrosniak. 1991. Evidence for increased cancer rates related to radon in well water. $p$. 213-243.

Roessler, C.E., W.E. Bolch, B. Birky, and G.S. Roessler. 1991. Dose estimation and risk assessment for naturally occurring radionuclides in agricultural products. $p$. 194-212.

Shibles, D.B., and T.C. Riddle. 1991. Levels of Radium-226 in crops grown on phosphatic clay at the Polk County Mined Lands Agricultural Research/Demonstration Project. p. 260-275.

Staples, C.R., R. Umana, J.A. Stricker, D. Shibles, M.J. Hayen, C.D. Hissem, D.S. Lough, and D.L. Demorest. 1991. Radionuclides in milk of dairy heifers raised on forages harvested from phosphatic clay soils on reclaimed mined land. p. 146-163.

Stricker, J.A., S.L. Sumner, D.B. Shibles, R.L. West, and E.A. Hanlon. 1991. Naturally occurring radionuclides in tissue from beef fed forages grown on phosphatic clay. p. 276-290. 
Valenti, J.M., and M.A. Ferguson. 1991. Communicating environmental risk to risk takers. p. 291-317.

Walsh, P.J. 1991. Radioactivity in foods: Putting the risk in perspective. p. 174-193.

\section{Reports and Dissertations}

Guidry, J.J. 1990. Radioactivity in foods grown on mined phosphate lands. FIPR Pub. No. 05-028-088, Bartow, FL.

Hanlon, E.A., R.A. Jerez, and J.A. Stricker (eds.) 1996. The mined lands agricultural research and demonstration project: Summary of experiments and extension recommendations. Florida Institute of Phosphate Research. Bartow, FL. Pub. No. 03-093-128. 115 pp.

The following article is found in the reference cited above in bold font.

Hanlon, E.A., R.A. Jerez, J.A. Stricker, D.B. Shibles, and T.C. Riddle. 1996. Naturally occurring radionuclides in agricultural products. p. 16-26.

Shibles, D.B. (ed.) 1994. Polk County mined lands agricultural research/demonstration project report: Three-year summary. Florida Institute of Phosphate Research. Bartow, FL. FIPR Publ. No. 03-088-107.

The following articles are found in the reference cited above in bold font.

Shibles, D.B., and T.C. Riddle. 1994. Levels of 226Ra in crops grown on phosphatic clay at the Polk County mined lands agricultural research/demonstration project. p. 51-60.

Staples, C.R., R. Umana, J.A. Stricker, D. Shibles, M.J. Hayen, C.D. Hissem, D.S. Lough, and D.L. Demorest. 1994. Excretion of radionuclides in milk of dairy heifers fed forages harvested from phosphate mined reclaimed soils. p. 71-82.
Stricker, J.A., E.A. Hanlon, R.L. West, D.B. Shibles, S.L. Sumner, and R. Umana. 1994. Naturally occurring radionuclides in tissue from beef fed forages grown on phosphatic clay. p. 61-70.

\section{Extension Publications}

Hanlon, E.A. 1991. Summary of the proceedings from the national symposium on radionuclides in agricultural products. Mined Lands Agricultural Research/Demonstration Project. Fla. Coop. Extn. Serv., IFAS, Univ. of Fla., Gainesville, FL. 4 pp.

Hanlon, E.A. 1994. Naturally occurring radionuclides in agricultural products. Univ. of Fla., IFAS, Coop. Extn. Serv. SS-MLR-5. 5 pp.

Hanlon, E.A. 2005. Naturally occurring radionuclides in agricultural products. UF/IFAS Publication Number SL-221.

\section{Presentations, Videos, and Training Sessions}

Field Day. 1991. Naturally occurring radionuclides in agricultural products grown on phosphatic clays. Media specialists field day. Bartow, FL.

Hanlon, E.A. 1991. Moderator and chair. National Symposium on naturally occurring radionuclides in agricultural products. Florida Coop. Ext. Serv. Orlando, FL., 24-25 Jan.

Stricker, J.A., S.L. Sumner, D.B. Shibles, R.L. West, and E.A. Hanlon. 1991. Naturally occurring radionuclides in tissue from beef fed forages grown on phosphatic clay. Symposium on naturally occurring radionuclides in agricultural products. Florida Coop. Ext. Serv. Orlando, FL., 24-25 Jan. 


\section{Equipment for agricultural activities} on phosphatic clay

\section{Journal Articles}

Shaw, L.N. 1995. Cable drawn drainage plough for land reclamation in unconsolidated phosphatic talbot, clay sediments. J. Agric. Eng. Res. 62, 215-219.

\section{Reports and Dissertations}

Shibles, D.B. (ed.) 1994. Polk County mined lands agricultural research/demonstration project report: Three-year summary. Florida Institute of Phosphate Research. Bartow, FL. FIPR Publ. No. 03-088-107.

The following articles are found in the reference cited above in bold font.

Shaw, L.N. 1994. Cable powered drain plow and soil moving systems (1990-1991). p. 127-132.

Shaw, L.N. 1994. Powered bedder (1990-1991)—First prototype. p. 117-122.

Shaw, L.N. 1994. Punch planter for vegetable crops. p. 133-136.

Shaw, L.N. 1994. Rotary dibble for planters. p. 126-127.

Shaw, L.N. 1994. Whirlwind terracer and rotary ditcher evaluations (1990-1991). p. 123-125. 